\title{
DISCLOSURE OF CORONAVIRUS DISEASE-19 (COVID-19) PATIENT DATA: ETHICAL AND LEGAL PERSPECTIVES IN INDONESIA
}

\author{
Rani Tiyas Budiyanti ${ }^{\star 1}$, Penggalih Mahardika Herlambang ${ }^{2}$ \\ ${ }^{1}$ Health Policy and Administration, Faculty of Public Health, Universitas Diponegoro, Semarang, \\ Indonesia \\ ${ }^{2}$ Faculty of Medicine, Universitas Wahid Hasyim, Semarang, Indonesia \\ ranitiyas89@gmail.com
}

\begin{abstract}
The contact tracing policy strategy implemented during the COVID-19 pandemic requires data on COVID-19 patients to be accessible to the public so that people who have been in contact with the positive patient can do self-isolate. However, this is contrary to medical secrets and the confidentiality of COVID-19 patient data as a form of private law. This research is normative research with a statutory approach (statue approach) and conceptual (conceptual approach). Based on ethical and legal aspects, the confidentiality of COVID-19 patient data must be maintained. This data can be disclosed with the patient consent or disclosed to the Health Office to conduct epidemiological investigations. Suppose the contact investigation involves several parties: the neighborhood unit, the village head, Village Community Empowerment Service, police, and other parties. In that case, further regulation is needed to ensure the commitment of these parties in maintaining COVID-19 patient data. Disseminating patient data openly or publicly can make harm to the patient, especially in the not good environment with risk of stigmatization. There is also a need for harmony between existing regulations and the programs or policies implemented by the government.
\end{abstract}

Keywords: Data Disclosure; COVID-19; Ethical and Legal Perspective

\begin{abstract}
Abstrak
Strategi kebijakan Contact tracing yang diterapkan selama pandemic covid-19, menuntut data pasien COVID-19 untuk dapat diakses oleh publik, sehingga masyarakat dapat melakukan isolasi mandiri jika sekiranya pernah berkontak dengan pasien positif tersebut. Akan tetapi hal tersebut bertentangan dengan rahasia medis dan kerahasiaan data pasien COVID-19 sebagai bentuk hukum privat. Penelitian ini merupakan penelitian normatif dengan pendekatan perundang-undangan (statue approach) dan konseptual (conceptual approach). Berdasarkan aspek etika dan hukum, kerahasiaan data pasien COVID-19 harus dijaga. Data ini dapat dibuka dengan persetujuan pasien atau dibuka kepada Dinas Kesehatan untuk melakukan investigasi epidemiologi. Jika invesitigasi kontak melibatkan beberapa pihak seperti rukun tetangga, kepala desa, Dinas Pemberdayaan Masyarakat Desa, polisi, dan pihak lainnya maka diperlukan regulasi lebih lanjut untuk memastikan komitmen oihak tersebut dalam menjaga data pasien COVID-19. Penyebarluasan data pasien secara terbuka atau publik dapat merugikan pasien terutama pada lingkungan yang kurang mendukung dengan resiko stigmatisasi yang cukup tinggi. Diperlukan pula keselerasan antara regulasi yang ada dengan program atau kebijakan yang diterapkan oleh pemerintah.
\end{abstract}

Kata Kunci : Pembukaan Data; COVID-19; Aspek Etika dan Hukum 


\section{A. Introduction}

Coronavirus disease-19 (COVID-19) is the disease that is caused by the SARS-COV-2 virus. ${ }^{1}$ The first case was announced in Wuhan in December 2019. ${ }^{2}$ Unfortunately, these cases increase day by day and spread over the world. Therefore, World Health Organization has declared COVID-19 as a pandemic and public health emergency of international concern. ${ }^{3}$ Until April 2020, the cases in the world were over two million, with more than 150,000 deaths. ${ }^{4}$

Indonesia is the country in South East Asia that also has the COVID-19 cases. Until December $29^{\text {th }}, 2020$, the number of positive cases that have been confirmed was 727,122 cases with 21,703 deaths and 596,783 recovered patients. ${ }^{5}$ The first and second confirmed cases were announced on March $2^{\text {nd }}, 2020$. It was found in contact tracing after a tourist that had stayed in Indonesia for many days was confirmed positive for COVID-19. ${ }^{6}$

The number of COVID-19 positive cases in Indonesia was increased day by day. Many strategies have been done include of strengthening tracing, tests, and treatment. ${ }^{7}$ In this case, public information related to COVID-19 patient data was needed. Personal identity is used for community tracing and knowing people who get COVID-19, who and how many people have primary and secondary contacts with them, etc. This information is also important to classify people who are suspects, get early screening and treatment, and do self-isolation so that they can prevent the spread of COVID-19.

However, it is a dilemmatic problem whether the data of confirmed patients should be disclosed or not. It is related to the confidentiality of COVID-19 patient data. On the other hand, stigma is still a problem in Indonesia. In the first and second cases, many media in Indonesia announced the identity and chronology, and even the personal identity has spread to all people. Many people judged and shunned them. It makes people with confirmed COVID-19 feel depressed. ${ }^{8}$ The rejection also happens to the dead bodies of COVID-19 patients. They are

1 World Health Organization (WHO). Coronavirus Disease 2019 (COVID-19) Situation Report- 32. 21 February 2020

2 World Health Organization (WHO). Archieved: WHO Timeline-COVID 19. 27 April 2020.

3 World Health Organization (WHO). Rolling updates on Coronavirus Disease 2019. 2020

4 Worldometer. COVID-19 Coronavirus Pandemic. 2020

5 Indonesian COVID-19 Task Force. 2020. Available from : https://covid19.go.id/

6 World Health Organization. Media Statement on Confirmed COVID-19 Cases. $2^{\text {nd }}$ March 2020

7 Kementrian Kesehatan Republik Indonesia. Panduan Singkat Pelacakan Kontak (Contact tracing) Untuk Kasus COVID-19 tahun 2020. Available from https://infeksiemerging.kemkes.go.id/download/Contact Tracing mobile size revisi7.pdf

8 Sulistiyadi W, Rahayu S, Harmany N. Handling of Public Stigma in Indonesian Society. Kesmas: Jurnal Kesehatan Masyarakat Nasional (National Public Health Journal). 2020; Special Issue 1: 70-76 
scared that the corpse of the COVID-19 patient still can transmit the SARS-COV-2 viruses to the community. ${ }^{9}$

There are also many cases related to COVID-19 stigma and discrimination not only against covid-19 patients but also against many health professionals. ${ }^{10}$ In many areas in Indonesia, they have been rejected by the community, and it makes many local governments get them a designated place as the shelter during the COVID-19 pandemic. Therefore, they must stay at hotels and other places that the government prepared. ${ }^{11}$ Furthermore, the community rejected the burial of common people, but they also rejected the burial of health professionals who died from COVID-19. ${ }^{12}$

Thus, This article will discuss and explore the ethical and legal perspectives of COVID-19 patients' data disclosure in Indonesia.

\section{B. Methods}

This research used normative legal research with the statue and conceptual approach. The research was done from October until December 2020. The data was collected from literature research that used primary, secondary, and tertiary legal materials. The literature research is also sourced from journals, e-book, and proceedings related to patient data disclosure, patient data regulation, patient data confidentiality and privacy, patient data during COVID-19 pandemic, patient data during a pandemic, or extraordinary event, and implication of patient data disclosure.

\section{Result and Discussion}

\section{Patient Data Privacy and Confidentiality}

Confidentiality of personal data is a right of individual data subjects. This relates to the purpose of data collection and processing, data use, confidentiality, and the way institutions

9 Luthfia Ayu A. 2020. Penolakan Jenazah Pasien COVID-19, Mengapa bisa Terjadi? Available from : https://www.kompas.com/tren/read/2020/04/13/110821765/penolakan-jenazah-pasien-covid-19mengapa-bisa-terjadi?page=all

10 Vitorio Mantalean. Rawat Pasien COVID-19, Tenaga Medis diusir dari Kos hingga harus Menginap. 25 March 2020. Available from : https://megapolitan.kompas.com/read/2020/03/25/14090911/rawatpasien-covid-19-tenaga-medis-diusir-dari-kos-hingga-harus-menginap?page=all

11 Sulistiyadi dkk, op.cit

${ }^{12}$ Candra Setia Budi. 2020. Pemerintah Kabupaten Semarang prihatin adanya Penolakan Pemakaman Perawat yang Positif Corona. Available from https://regional.kompas.com/read/2020/04/09/21034501/pemkab-semarang-prihatin-adanyapenolakan-pemakaman-perawat-yang-positif 
manage personal data. Thus, national regulations regarding data confidentiality often regulate the process of data collecting, using, sharing, storing, and deleting. ${ }^{13}$

Because this right is owned by everyone, the use of personal data is carried out at the authority of the individual. Data owners have the right to allow data managers to process and use their data. However, when data is used, the data owner has the legal right to request information about their own digital identity and has a purpose in using the personal data, as well as information about the institution requesting the data. ${ }^{14}$

In general, Indonesia also has regulations regarding the protection of personal data as stated in the Minister of Communication and Information Technology Regulation Number 20 year 2016 concerning Personal Data Protection (PDP). According to the PDP regulation, the owner of personal data has the right to the confidentiality of his data; the right to file a complaint in the context of resolving personal data disputes, the right to have access to historical personal data, and the right to request the destruction of certain personal data belonging to him in the electronic system. Matters related to this right are regulated in Article 26 of the PDP Ministerial Regulation.

Meanwhile, the obligations of users of personal data are in the form of maintaining the confidentiality of personal data obtained, collected, processed, and analyzed; obliged to use personal data according to user needs only; protect personal data and documents containing personal data; and is responsible for the personal data contained in its control.

In health care area, patient data are an important aspect. It must be written in both paperbased and electronic medical records. This record is important to know the history of a patient so that the patient can get the suitable treatment based on their health history. There are two variables in the medical record. The first is the personal identity, and the second is the health data. Personal identity contains name, address, age, gender, telephone number, family number, etc. Meanwhile, health data are related to the patient history, patient examination, diagnostic, treatment, and prognosis. ${ }^{15}$

In Indonesia, the privacy of patient data is also ensured with Article 7 Law Number 36 of 2009 on Health, Article 48 Law Number 29 of 2004 about Medical Practice, and Article 32 point (i) Law Number 44 of 2009 on Hospital. It has also been guaranteed in Regulation of the Ministry of Health Number 269 of 2008 on Medical Record, and also Law number 36 year 2012 on Health Secrets.

13 Ameed, M., \& Natgunanathan. (2016). Protection of big data privacy. IEEE Access, 1821-1834.

14 Tourkochoriti, I. (2016). The Snowden revelations, the Transatlantic Trade and Investment Partnership and the divide between US-EU in data privacy protection. University of Arkansas at Little Rock Law Review 36, 161-176.

15 Mathioudakis, A;Rousalova I; Gagnat AA; Saad Neil; and Hardavella Georgia. How To Keep Good Clinical Records? Breathe (Sheff). 2016 


\section{Biomedical ethics and Public Health Ethics}

Patient data security and confidentiality are things that must be met in health services. With regard to biomedical ethics, the most important thing to do is "primum non nocere" or first do no harm. Patient data must be kept confidential because it relates to the patient's rights, as well as considerations that arise due to data leakage. Personal data such as name, population identification number (NIK), mobile phone number, mother name, and so on can be misused if widely spread, one of which is related to banking problems.

Then, medical data that is widely spread also can make stigmatization until a cyberattack that related to patient services. In relation to patient data, there is also an aspect of autonomy in biomedical ethics where the patient has the right to make decisions about himself, including the data he has.

However, individual health data are also needed in the context of public health. Eighty-five percent of all current health data is electronic. With the proliferation of disease outbreaks as well as the need for rapid access to patient health care data, electronic exchange of information between public health and healthcare is essential. ${ }^{16}$ Some health-related research such as the cause of a disease, treatment and so on that are useful for the community also require personal health data. This health-related data is also needed to show public health conditions such as mortality rates, number of cases, and so on and as a basis for policymaking. However, often aggregated data is used instead of data by name by address, so that personal confidentiality is still maintained.

\section{Disclosure of Confirmed COVID-19 Patient Data}

During the COVID-19 pandemic, patient data was a need as public information to strengthening tracing, test, and treatment. It is useful for the community, research, and policy aspect. However, every patient has the right to privacy and confidentiality of their illness, including their medical data. This is regulated in Article 32 (i) Law Number 44 of 2009 on Hospital.

These rights are also regulated in Article 57 paragraph (1) of Law Number 36 the year 2009 on Health and Article 17 (h) number 2 of Law Number14 year 2008 on Openness of Public Information that state every person has the right to the confidentiality of their personal health conditions that have been disclosed to health service providers and every public body is obliged to open access for every applicant for public information except history condition and treatment,

16 CDC.Surveilance Strategy Report-How Sharing Data Digitally Benefits Health. Available from: https://www.cdc.gov/surveillance/innovation/sharing-data-digitally.html 
medical treatment, physically and psychologically a person, because if it is opened, it can reveal personal secrets.

In the case that doctor or dentist fails to fulfill the obligation in Article 46 paragraph (1) and article 51 letter $\mathrm{c}$ in the Law Number 29 of 2004, they can be punished with a maximum fine IDR 50 million based on Article 79 letter b and c Law Number 29 of 2004 juncto Constitutional Court Decision Number 4/PUU-V/2007.

Regarding patient rights and hospital obligations, every hospital must keep medical secrets, which can only be disclosed for the benefit of patient health, to fulfill request from law enforcement officials in the context of law eforcement, with patient consent, or based on the provisions of statutory regulations. ${ }^{17}$

Based on other regulations, the Decree of Ministry of Health Number 413 on Guidelines for Prevention and Control of Coronavirus Disease 2019 (COVID-19), data can be disclosed in a restricted manner for preventive action with or without patient permission. All suspect cases, probable cases, and confirmed cases should be reported to Public Health Office to get an epidemic investigation.

This condition in line with Decree of the Medical Ethics Honorary Council No. 015 / PB / K.MKEK/ 03/2020 concerning Medical Ethics Fatwas, Health Policies, and Research in the Context of the COVID-19 Pandemic, which states medical secrecy related to the interest of collecting information can be revealed in certain circumstances.

So, based on the regulations, it is clear that individual data on COVID-19 patients only can be disclosed with the patient's consent, fulfill the request from law enforcement officials, or for reporting to the Public Health Office in the context of contact tracing. But, in fact, contact tracing and support to COVID-19 patient that do self isolation, not only carried out by the Health Office but also involves other sectors such as the local community, headman, police, and other parties.

For example, in Central Java Province, there has been "Jogo Tonggo" Program that involves the community to support the confirmed COVID-19 positive people and prevent the spread of COVID-19. In Jogo Tonggo, there are many tasks related with health, economic, security, and entertainment aspects. ${ }^{18}$ In the health aspect, they cooperate to support people with confirmed COVID-19, identify the people who enter and leave the area, and also screen the health condition in the village community. In the economic aspect, the community helps each other by building food supplies storage. People who need food supply can take it for free. In the security aspect, they are responsible for the village security during the COVID-19 pandemic,

17 Law Number 29 of 2004 about Medical Practice

18 Shofi, Rizani. 2020. Apakah Pelaksanaan Jogo Tonggo di Dusun Pelem Kabupaten Rembang Efektif? Jurnal Kebijakan Kesehatan Indonesia Vol 9 No.4 
while in the entertainment aspect, many communities do pleasure activities during pandemic in their home. ${ }^{19}$

In West Java Province, there has been a similar program that was called "SALIRA". This program also involves the Public Health Office, Community and Village Empowerment Service local community, headman, police, and other parties to do contact tracing, education on health protocol, and reduce stigmatization on COVID-19 patients. ${ }^{20}$

In terms of involving parties other than the health office in contact tracing, further regulations are needed to ensure the commitment and consent of the parties involved to keep the confidentiality of COVID-19 patient data. Patient data will become big data that contain variety, value, and velocity data related to COVID-19.

Another challenge that can happen when more parties are involved is the protection of patient data more difficult. In Indonesia, there are still problems related to data security and data disclosure. Data related to the health status of COVID-19 patients are useful for research and policy. ${ }^{21}$ For example, if there are data related to old age and comorbidities that have a greater impact on COVID, the policy will guard older people with comorbidities. However, the classified data should be considered in the report system. It should consider whether the data should be reported by name and address or only in community data and at what level the data are needed. Healthcare facilities should keep this data secret, although healthcare should report the patient data in the pandemic event. However, patient data privacy should be ensured.

For collective data, healthcare can report the number of COVID-19 cases in their area without revealing patients' identities. ${ }^{22}$ Patient data's health characteristics and identity can also be reported, but it is only limited to gender, age, comorbidities, and treatment. Healthcare should differ the identity data and medical data and make encryption to guarantee it. It is useful for strategies if someday there is a cyberattack on the medical record, a data breach will not have a harmful effect on the patient, for example, a data breach that reveals the full identity of patients and spreads them to the public, which can affect the patients in the form of stigmatization, personal bullying, political harassment, etc.

19 Ibid

20 Pemerintah Daerah Provinsi Jawa Barat. Jawa Barat Perkuat Penanganan Covid di Desa dengan SALIRA. $\quad 9 \quad$ Februari $2021 . \quad$ Available from: https://jabarprov.go.id/index.php/news/41250/2021/02/09/Jawa-Barat-Perkuat-Penanganan-Covid-19di-Desa-dengan-SALIRA

21 Indonesian PWYP. 3 July 2020. One Data Policy in Pandemic Era: Story from West Nusa Tenggara and Semarang Province. Available from : https://pwypindonesia.org/en/one-data-policy-in-thepandemic-era-story-from-west-nusa-tenggara-and-semarang-provinces/

22 Cipta Pramana, Susi Herawati, Nur Santi, Rosreri, Luh Putu Endyah Santi Maryani, Oktina Rachmi D. 2020. The First Case of COVID-19 in Semarang Indonesia : A Case Report. International Journal of Pharmaceutical Research, Apr-Jun 2020, Vol 12: 2 
In practice, it is important to know positive patients' identities. But on the other hand, the stigma and discrimination in the community are also problematic. In biomedical ethics, the first important principle is non-maleficence or to do no harm.

Stigma related with negative attitudes or discrimination against someone based on distinguishing characteristics such as mental illness, health conditions, or disabilities. ${ }^{23}$ Stigma can be divided into the internal and external stigma. Internal stigma comes from oneself, and external or social stigma comes from the outside environment.

As a new disease, much remains unknown about the COVID-19 pandemic. Moreover, humans tend to be afraid of it. This is what causes social stigma and discrimination against certain ethnicities and also people suffering from this disease. The feeling of confusion, anxiety, and fear felt by the community can be understood, but that does not mean stigma and discrimination against certain ethnicities that people can have prejudice and blame COVID-19 patients, nurses, families, or those who are not sick but have symptoms similar to COVID-19.

If it continues, social stigma can make people hide their illness, so they are not discriminated against again because this discrimination will cause COVID-19 patients to not immediately seek medical assistance and make them unable to get immediate treatment. Late treatment can increase the severity level of COVID-19 patients and increase morbidity. Stigmatization is also a barrier in contact tracing to identify the people contacted with COVID-19 patients.

Rural and urban environments have different characteristics of people. Hence, it should be serious consideration to disclose data in the not accepted environment. Therefore, stigma, discrimination, and also the mental health of the patient must be considered. However, on the other hand, data disclosure in a good environment can make the patient get well supported mentally and receive support in the form of daily needs during isolation.

Besides the environment, the awareness of patients with confirmed COVID-19 is needed. There are many cases in which patient with confirmed COVID-19 refuses isolation or treatment in a designated facility. They leave the hospital and self isolate against medical advice. However, in many cases, there are some people who fail to self-isolate. Many people did the test and already be confirmed positive for COVID-19, who have been found going to the public area such as wedding parties, markets, etc., and being super spreader. ${ }^{24}$ In this condition, the confirmed patient should be monitor by the public health officers that can collaborate with the head village so that the positive people discipline to do self-isolation.

23 Jenney Caddel. What is Stigma? 3 July 2020. Available from : https://www.verywellmind.com/mentalillness-and-stigma-2337677

24 Mahale P, Rothfuss C, Bly S, et al. Multiple COVID-19 Outbreaks Linked to a Wedding Reception in Rural Maine-August 7-September 14, 2020 


\section{Conclusion}

Based on the research, it is clear that individual data on COVID-19 patients can be disclosed with patients' consent, fulfill a request from law enforcement officials, or report to the Public Health Office in the context of contact tracing. Suppose contact tracing involves other sectors such as the local community, headman, police, and other parties. In that case, further regulations are needed to ensure the commitment and consent of the parties to keep the confidentiality of COVID-19 patient data. The benefit and the harm of data disclosure, especially patient stigma, need to be considered. Patient consent, environment support, patient awareness, and the role of local and community around should be considered before data disclosure.

\section{REFERENCES}

\section{Journal:}

Ameed, M., \& Natgunanathan. (2016). Protection of big data privacy. IEEE Access, 1821-1834

Mahale, Parag, Craig Rothfuss, Sarah Bly, Megan Kelley, Siiri Bennett, Sara L. Huston, Sara Robinson. Multiple COVID-19 Outbreaks Linked to a Wedding Reception in Rural MaineAugust 7-September 14, 2020. MWWR Morb Mortal Wekly Rep 2020;69:1686-1690

Mathioudakis, A, Rousalova I, Gagnat AA, Saad Neil, and Hardavella Georgia. How To Keep Good Clinical Records? Breathe (Sheff). 2016 Dec; 12(4): 369-373.

Pramana, Cipta, Susi Herawati, Nur Santi, Rosreri, Luh Putu Endyah Santi Maryani, Oktina Rachmi D. 2020. The First Case of COVID-19 in Semarang Indonesia : A Case Report. International Journal of Pharmaceutical Research, Apr-Jun 2020, Vol 12: 2

Shofi, Rizani. 2020. Apakah Pelaksanaan Jogo Tonggo di Dusun Pelem Kabupaten Rembang Efektif? Jurnal Kebijakan Kesehatan Indonesia. Vol 9 No.4. Available from : https://jurnal.ugm.ac.id/jkki/article/view/61712

Tourkochoriti, I. (2016). The Snowden revelations, the Transatlantic Trade and Investment Partnership and the divide between US-EU in data privacy protection. University of Arkansas at Little Rock Law Review 36, 161-176.

W, Sulistiyadi,Rahayu S, Harmany N. 2020. Handling of Public Stigma in Indonesian Society. Kesmas: Jurnal Kesehatan Masyarakat Nasional (National Public Health Journal). Special Issue $\quad 1$ : 70-76 . Available from : http://journal.fkm.ui.ac.id/kesmas/article/download/3909/1015

\section{Website Article:}

A, Luthfia Ayu. 2020. Penolakan Jenazah Pasien COVID-19, Mengapa bisa Terjadi? Available from : https://www.kompas.com/tren/read/2020/04/13/110821765/penolakan-jenazahpasien-covid-19-mengapa-bisa-terjadi?page=all (Accesed : 8 November 2020) 
Centers for Disease Control and Prevention.Surveilance Strategy Report-How Sharing Data Digitally Benefits Health. Available from: https://www.cdc.gov/surveillance/innovation/sharing-data-digitally.html

Indonesian PWYP. 3 July 2020. One Data Policy in Pandemic Era: Story from West Nusa Tenggara and Semarang Province. Available from : https://pwypindonesia.org/en/onedata-policy-in-the-pandemic-era-story-from-west-nusa-tenggara-and-semarang-provinces/ (Accesed : 8 November 2020)

Indonesian COVID-19 Task Force. 2020. Available from : https://covid19.go.id/

Jenney Caddel. What is Stigma? July $3^{\text {rd }}$, 2020. Available from: https://www.verywellmind.com/mental-illness-and-stigma-2337677

Kementerian Kesehatan Republik Indonesia. Panduan Singkat Pelacakan Kontak (Contact tracing) Untuk Kasus COVID-19 tahun 2020. Available from: https://infeksiemerging.kemkes.go.id/download/Contact Tracing mobile size revisi7.pdf

Mantalean, Vitorio. Rawat Pasien COVID-19, Tenaga Medis diusir dari Kos hingga harus Menginap. 25 March 2020. Available from : https://megapolitan.kompas.com/read/2020/03/25/14090911/rawat-pasien-covid-19tenaga-medis-diusir-dari-kos-hingga-harus-menginap?page=all $\quad$ (Accessed: 7 October 2020)

Pemerintah Daerah Provinsi Jawa Barat. Jawa Barat Perkuat Penanganan Covid di Desa dengan SALIRA. $\quad 9$ Februari 2021. Available from: https://jabarprov.go.id/index.php/news/41250/2021/02/09/Jawa-Barat-PerkuatPenanganan-Covid-19-di-Desa-dengan-SALIRA

Setia Budi, Candra. 2020. Pemerintah Kabupaten Semarang prihatin adanya Penolakan Pemakaman Perawat yang Positif Corona. Available from : https://regional.kompas.com/read/2020/04/09/21034501/pemkab-semarang-prihatinadanya-penolakan-pemakaman-perawat-yang-positif (Accessed: 9 November 2020)

World Health Organization (WHO). Coronavirus Disease 2019 (COVID-19) Situation Report- 32. February $21^{\text {st }}$, 2020. Available from: https://www.who.int/docs/defaultsource/coronaviruse/situation-reports/20200221-sitrep-32-covid-19.pdf (Accessed : 20 September 2020)

World Health Organization (WHO). Archieved: WHO Timeline-COVID 19. April $27^{\text {th }}, 2020$. Available from: https://www.who.int/news/item/27-04-2020-who-timeline---covid-19 (Accessed in September $\left.21^{\text {st }}, 2020\right)$

World Health Organization (WHO). Rolling updates on Coronavirus Disease 2019. 2020. Available from: https://www.who.int/emergencies/diseases/novel-coronavirus2019/events-as-they-happen . (Accesed : October $\left.2^{\text {nd }}, 2020\right)$

Worldometer. COVID-19 Coronavirus Pandemic. 2020. Avaliable from: https://www.worldometers.info/coronavirus/ . (Accesed : October $3^{\text {rd }}, 2020$ )

World Health Organization. Media Statement on Confirmed COVID-19 Cases. $2^{\text {nd }}$ March 2020. Available from: https://www.who.int/indonesia/news/detail/02-03-2020-media-statementon-covid-19 


\section{Regulations:}

Law Number 36 of 2009 concerning Health in Indonesia

Law Number 29 of 2004 concerning Medical Practice in Indonesia

Indonesian Ministry of Health Regulation Number 269 of 2008 concerning Medical Record

Law number 32 of 2012 concerning Health Secrets in Indonesia

Indonesian Ministry of Health Decree Number 413 concerning Guidelines of Prevention and Controlled Coronavirus Disease 2019 (COVID-19)

Minister of Communication and Information Technology Regulation Number 20 year 2016 concerning Personal Data Protection (PDP)

The Medical Ethics Honorary Council Decree No. 015 / PB / K.MKEK/ 03/2020 concerning Medical Ethics Fatwas, Health Policies, and Research in the Context of the COVID-19 Pandemic, 